\title{
RECIPROCAL Q/A PRESENTATION: WHAT IT MEANS TO THE STUDENTS
}

\author{
Furqanul Aziez \\ Universitas Muhammadiyah Purwokerto
}

\begin{abstract}
This study explores (1) students' perception of the implementation of 'Reciprocal Q/A Presentation' (Reqap) as a method, which is developed on three pedagogical principles: student centered learning, English as a medium of instruction (EMI), and authentic evaluation; (2) the anxiety level the students experienced during the classes using Reqap; and (3) their expectations of Reqap method. The respondents were students of the fifth semester at the English Department of Education and Teacher Training Faculty at Muhammadiyah University of Purwokerto, Indonesia. It randomly took 41 out of 102 students of the semester. This research was descriptive in nature. The data were gathered through closed and open questionnaires. The findings revealed that (1) on average students had good perception of Reqap method (4.02) and (2) the students' anxiety was at severe level (10.93), and (3) from the open questionnaire the data shows that (a) though it caused the high level of anxiety, the use of EMI brought about awareness in the importance of vocabulary and grammar, (b) authentic evaluation helped create positive backwash on the learning, (c) Reqap made students exerted themselves more, and (d) Reqap facilitated class management. The implications of this study point to the importance of using teaching methods characterized by student centered learning, EMI, and authentic evaluation.
\end{abstract}

Keywords: student centered learning, reciprocal presentation, anxiety level, authentic evaluation, English as a Medium of Instruction (EMI),

\section{Introduction}

Teaching practice in Indonesian schools still exhibits domination of teachers in the class. One research (Azmi, 2014) disclosed for instance that though teachers were fully aware that teachers must not take up too much time during instruction they still dominated the activities. The data indicated that despite most teachers believed that teacher talk time must not excede $40 \%$, observation data demonstrated that the ratio of the teacher talk time and students talk time was 70:30. Of the $70 \%$ of the talk, the most was spent on explaining, which took up more than one third $(33.84 \%)$. The second most time consuming teacher talk was for giving direction $(17.90 \%)$ and the third most time taking was accepting students' response. This picture was more or less the same as demonstrated by other research which showed that teachers talk could reach up to $70 \%$ of the total talk (Cook, 2000; Chaudron, 1988; Zhao Xiaohong, 1998 cited in Xiao-yan, 2006: 6).

With this type of teaching practice, it would be difficult to expect active classes where students are intensively involved in the classroom activities. As Esfandari and Knight
(2013) put it one key element of modern approaches to language teaching is that students learn by doing and experience them. This is much more obvious in EFL classes, in which students do not live in an Englishspeaking environment. They need bigger opportunity to practice the target language in the classroom. This teaching practice as spotted in many Indonesian classrooms may result from the teachers' experience during their study in the teacher training program, where they were also taught with the same strategy.

Indeed, lecturers in teacher training institutions still show a variety of views of what good instruction is like. Pre-research revealed that some lecturers adopted teacher centered learning approaches, in the belief that this method enabled them to extensively explore and elaborate what they had to deliver to the students. They also code-mixed from bahasa Indonesia to English in their classes. They do so for the reason that they cannot take the risk of leaving the students 'getting nothing' after the class for the mere sake of English use. As for the evaluation, most lecturers prefer objective tests for a very understandable view: practicality. 
With these circumstances in mind and with the persistently prevailing problems of students' competence in grammar and vocabulary and their performance in speaking skill, the writer has instigated an instructional strategy which evolves from three main concepts: student-centered teaching, English as a medium of instruction (EMI), and authentic evaluation.

The choice of student-centered teaching concept for this method was based on the assumptions that acquisition of knowledge well through interaction among learners in a socially meaningful context. For EFL learners the adoption of this concept would lead to at least two clear destinations: language and knowledge. Student-centered learning as in collaborative learning is characterized with the assignment of students into groups and members of the groups interact together to achieve a certain goal or find a solution to a specific learning outcome (Farrah, 2011). In other words student-centered learning refers to a variety of teaching methods or activities in which students work together to learn and help their teammates learn in order to accomplish a common shared goal (Johnson \& Johnson, 1999).

According to Astin (1993), this type of learning provides a social context for learning where interaction among learners is increased and therefore leads to successful learning experiences. It is in this interaction learners will get not only shared meaning but also language exposures. This positive side of student-centered learning is magnified by the fact that students' different background in terms of language proficiency, learning style, and experience contributes positively to the learning process and improves their problemsolving strategies as they are confronted with various interpretations for a problem-solving activity (Vygotsky, 1978; Bruner, 1985). As they are actively engaged in the transformation and transfer of shared knowledge, learners tend to be motivated to achieve the common goal and therefore learning will be a pleasant activity.

Within this theoretical framework, the use of English as a medium of instruction finds its best context. The use of EMI in Reqap surely provides students with target language exposures, which can rarely be found in a non -English speaking country like Indonesia. The use of English rather than Indonesian will help students achieve their ultimate goal. On the contrary, the use of native language is believed by many to harm the acquisition of the target language (Richards, 1971; Cook, 2001; Harbord, 1992). One of the arguments for the objection to the use of native language is the interference, which is the automatic transfer of the surface structure of the first language onto the surface of the target language (Dulay, Burt \& Krashen, 1982, as cited in Al-Harbi, 2010). For the reason the separation of L1 and L2 should be made (Richards, 1971; Cook, 2001). This view is supported by Krashen and Terrell (1983) who indicate that for there to be a successful learning of L2 the use of L1 should not be included in L2 classroom. The exclusion of L1 in L2 classroom is considered to be effective in increasing students' exposure to the target language. This is because students acquire L2 in the same way they acquire L1, which is through the exposures to the L1 use.

The implementation of student-centered learning approach and the use of EMI will be contextual if the achievement of the intended goals is measured through authentic evaluation. In this type of evaluation students are required to select and present ideas, and to reconstruct knowledge, in the form of tasks that reflect real-world needs. Authentic evaluation is also the measurement of intellectual accomplishments that are worthwhile and meaningful. Worthwile and meaningful because the construction of knowledge, disciplined inquiry, and strong character are indeed priorities of the current educational policies in Indonesia. As Wiggins (1989) claims authentic assessment values the thinking behind work, the process, as much as the finished product.

However, much has not been known of this method. For the reason, a research on students' perceptions and expectations of this method and anxiety they might experience must be carried out, and the results of which will be employed as the basis of improvement. Of course, further research on the effectiveness of this study must also be conducted.

\section{The Research Context}

This investigation took place in an Indonesian private university setting, where the respondents were the fifth semester students of the English Department at the Faculty of 
Education and Teacher Training, the University of Muhammadiyah Purwokerto, taking Language Testing 1 . The total number of students taking the subject was 112. They were divided into four classes of unequal number. Of the 112 students, 41 (two classes) were taken as the sample.

Language Testing 1 was developed to give necessary knowledge to the students of how to develop valid, reliable, and useful language tests. This knowledge background would be useful for them in the following semester when they had to take Language Testing 2, where had to construct tests and analyze the results.

At the beginning of every class, the lecturer discussed with the students about the rules, teaching activities, etc. for the semester. The lecturer also informed the students that they would apply three pedagogical concepts for the teaching: the student centered learning, EMI, and authentic evaluation.

For the first concept, the class would use the so-called 'reciprocal Q/A presentation'. Reqap follows the following procedure. First, the class was divided into twelve groups and each group was assigned a topic. Second, each group prepared a paper, slides, and five questions on the topic. Third, the groups handed in the papers and slides on the third week or the first week of the Reqap. Fourth, the second week was used by the lecturer to give an introduction to language testing. Fifth, the Reqap comprised three sessions. The first session was for the presenters to present the material in slides. The second session was for the presenters to pose five questions to the audience, in which the questions would be given to five different individuals by the lecturer at random. The third session was for the audience to ask questions to the presenters. Again, the lecturer would choose five participants among the audience who will ask the questions and presenters who will answer the questions.

Reqap itself was complemented with several rules as the following. First, during the presentation the lecturer sat among the audience observing what was going on in the presentation. He would interrupt if he saw concepts incorrectly explained or he thought that some more concepts could be added to complete the explanation. He would also made corrections to minor mistakes, commonly in grammar, vocabulary, and pronunciation. The correction was generally in the form of echoing (lecturer repeated the wrong with the correct). Second, he would stand up and went before the class if he saw a presenter speaking incomprehensibly. He would remind the speaker. If the speaker kept showing apparent insufficiency of language control, the lecturer would ask the speaker in question to hand over his turn to another member of the group. In case the low performance of the student might be caused by nervousness, the lecturer would give a second and third chance. If, however, the low performance persisted, the lecturer would stop and gave his/her turn to the other members.

For the second concept, EMI, the class had to use English only during the Reqap. Not even a word other than English was allowed to be used during the class, either by the presenters nor by the audience However, for the paper, the language was in bahasa Indonesia. This was done so because the source books were in English. The use of bahasa Indonesia would help reduce the possibility of plagiarism on the paper. Besides, the use of bahasa Indonesia for the paper would reinforce students understanding of the topics.

Authentic evaluation was administered comprehensively as it was applied not only to the final examination, but also to the paper and class activities during Reqap. The paper and slides would cover $10 \%$ of the total score, while presentation $40 \%$, asking questions $10 \%$, and answering questions $10 \%$, and final exam $30 \%$. Score for presentation was given individually and so was for posing and answering questions. Only score for paper was given in groups.

In short, the term Reqap refers to two subterms. The first is Reqap as a method, which is developed on three concepts: student centered learning, EMI, and authentic evaluation. The second stands for the teaching and learning activities (technique) which comprises three sessions (presentation, questions from the presenters, and questions from the audience) and the rules of the game.

\section{Sampling}

\section{Methodology}

The research was participated by English Department students of Teacher Training Faculty of The University of Muhammadiyah 
Purwokerto, Indonesia. The writer chose one class of the four in semester five taking Language Testing. There was no particular purpose for selecting the class. It was done merely because it appeared in the schedule at the first day (Monday) of the semester. The class was typical of teacher training departments in the university, where female students dominated. In the class sample the number of male students made up of only $10 \%$. This class consisted of 31 students.

\section{Instrumentation: Questionnaire}

This study used two questionnaires: closed and open questionnaires. The first was to address the research questions: 'What is the students' perception of Reqap?' and 'What is the students' level of anxiety?'. Beside students' perception of Reqap method, the questionnaire was designed to address students' perceptions of (1) the three sessions of Reqap: the presentation session, the presenter question session, and the audience question session; (2) the use of EMI; (3) the implementation of authentic evaluation; and (4) the possibility of using Reqap in other relevant classes. Other important data which was collected through this instrument was the most influencing factors causing anxiety. The part of the questionnaire which gathered data on anxiety was adapted from Horwitz's (1986) Foreign Language Classroom Anxiety Scale (FLCAS). The open questionnaire was developed to collect students' comments and/ or suggestions for the improvement of the method.

\section{Data Collection Technique}

The class lasted from September 7 to December 23, 2014. The class met sixteen times. Of the sixteen, two were used for credit contract and introduction to language testing, while giving time for students to prepare their presentation. Twelve meetings were used for the instruction using Reqap. The other two were for final examination. The data was collected at the last two meetings. The questionnaires were distributed while they were waiting for the interview calls. At the first day of the exam, students were asked to respond to the closed questionnaire while at the second day they were to respond to the open.

\section{Data Analysis}

Data analysis for the questionnaires could be explained as the following. There were two types of questionnaire, closed and open. For the closed questionnaire, there were two main questions. The two main research questions deal with students' perception of the Reqap method and students' anxiety level. However, the first main question was clarified by five secondary questions. They were Reqap as a presentation technique, EMI, most blocking language elements, authentic evaluation, and Reqap as an alternative method for other relevant classes. The second main research question was with one secondary question, which deals with the most influencing factors of anxiety.

Data analysis for the first main research question, perception of Reqap as a method was as the following. The questionnaire was a five scale one, with scale 1 for strongly agree, scale 2 for agree, scale 3 undecided/doubtful, scale 4 disagree, and scale 5 disagree. Scale 1 was valued 5 , scale 2 was valued 4 , scale 3 valued 3 , scale 4 valued 2 , and scale 5 valued 1 . Score for this part was obtained by first, multiplying the frequency of choice of each scale by the respective value. Second, the multiplication results of the five scales $(1-5)$ for each statement/item were added and third, the sum was divided by the number of the respondents (41). Fourth, the results of these divisions were summed up. And the fifth, this sum was then divided by the number of items on perception of Reqap as a method (11).

Data analysis for the first secondary question, perception of Reqap as a presentation technique, follows the same steps as the analysis above, except that the last sum was divided by the number of items on perception of Reqap as a presentation technique, which were six. Data analysis for the second secondary question, perception of EMI, followed the same steps as the first, except there was no division after the last sum was found, because item concerning this question was only one. For the third secondary question, perception of authentic evaluation, the analysis followed exactly the same as the second secondary question.

As for the data analysis of the fourth secondary question, perception of language elements which block communication most, the steps were like those taken at the first main 
question until step three, in which score for each item was summed up and then divided by the number of the respondents (41). And for the last secondary question, Reqap as an alternative method for other classes, the analysis took exactly the same steps as analysis for the the fourth secondary question.

Data analysis for the second main research question, the students' anxiety level, took the following steps. First, the same as the step taken for the first main question, each scale was multiplied by each respective value, in which scales were valued in reverse order, scale one was valued five and so forth. Second, the multiplication results of all scale in each item were then added. Third, the result of this addition was summed up. Fourth, the sum was divided by the number of the respondents (41). The maximum score for this calculation was fifteen (15) and the minimum was three (3). The maximum score was obtained by multiplying the number of items (3) and the highest value (5), while the minimum score was produced by multiplying the number of items (3) and the lowest value (1).

Data analysis for the secondary question after the second main question was different from the others. This was because it did not use Likert Scale, instead it used ranking. Respondents were asked to rank three most influential factors of anxiety (A. Students should master all presented material, B. Students should use EMI during instruction, and C. Final examination takes the form of authentic evaluation) in order of importance. Rank one was valued three, rank two was valued two, and rank three was valued one. The analysis step was very simple. Choice frequency was multiplied by value of each rank. The maximum score for this analysis was 102 and the minimum was 41. The maximum score was acquired by multiplying the number of respondents by the maximum value (3), while the minimum score was gained by multiplying the number of repondents by the minimum value (1).

Data analysis of the open questionnaire took the following steps. First, the comments and/ or suggestions were read through for the gists. Second, they were rewritten for ease of understanding. Third, they were grouped by the gist. Fourth, sentences having the same gist were represented by one, the rest were withdrawn. Fifth, the selected comments and/ or suggestions were displayed for interpretative discussions.

\section{Results and Discussions}

The results corresponded with the three main research problems: students' perception of Reqap, students' level of anxiety, and students' expectations of Reqap. For the first main problem, there were five secondary problems which were developed for the clarity of the main problem. Actually the data of the secondary problems were taken out from the main research problem. For the second main research problem, there was one secondary problem which was supposed to support the main problem. As for the third main research problem, results were grouped under comments and expectations. Below is the display of each of these problems.

\section{Main Problem 1}

\section{Students' Perceptions of Reqap as a Method}

As we can see in Table 1 given below, the results of the students' perceptions regarding Reqap as a method were generally positive. This can be seen from the mean scores (4.02) of the statements (i.e. items 1, 2, 3, 4, 4, 5, 6, 7, 11, $12,13,14)$ which address the first problem. Most of the students agreed that it was a good idea if the teacher decides who will speak first in the presentation as this will make the students prepare temselves better (4.32). This is of course surprising considering that random pointing does not allow segmentation of material and distribution of one segment for one student. Accordingly, this rule of presentation forces students to master the entire material as well. What is more surprising is that this statement gained the highest score, meaning that most students strongly agree with the rule.

The second hisghest scores, items 13 and 14, showed that students believed that Reqap could push them to master English and prepare themselves for the exam. They also strongly believed that Reqap caused them to study harder in order to perform well in the presentation. This was shown in the score of item 12 (4.17), which was slightly below the score of item 13 and 14. What was not surprising was the finding for item 3, regarding the termination of an individual presentation by the lecturer when considered he could not speak satisfactorily enough to make the audience understand him. This 
statement scored the second lowest (3.66). However, this score still allows us to interpret that most students agreed that for the sake of the whole presentation it would be better for a student who could not speak intellegibly to pass his turn to his group mates.

Table 1

Means and Standard Deviation of Students' Perceptions of Reqap as a Method

\begin{tabular}{|l|l|l|l|}
\hline \multicolumn{2}{|l|}{ Statements } & Means & SD \\
\hline 1 & $\begin{array}{l}\text { Lecturer's role to determine who will speak first in the presentation makes } \\
\text { students prepare themselves better. }\end{array}$ & 4.32 & \\
\hline 2 & $\begin{array}{l}\text { Lecturer's role as an observer who can interrupt and correct grammatical, } \\
\text { vocabulary, and pronunciation mistakes during presentation is beneficial. }\end{array}$ & 3.98 & \\
\hline 3 & $\begin{array}{l}\text { It is logical for the lecturer to stop a student's presentation if the student } \\
\text { cannot speak English satisfactorily because this will affect the whole } \\
\text { presentation. }\end{array}$ & 3.66 & \\
\hline 4 & $\begin{array}{l}\text { Presentation as a teching technique boosts students to master the teaching } \\
\text { material. }\end{array}$ & 4.10 & \\
\hline 5 & $\begin{array}{l}\text { Questions from presenters to audience can draw better attention from the } \\
\text { audience to what is being delivered by the presenters. }\end{array}$ & 4.17 & \\
\hline 6 & $\begin{array}{l}\text { Questions from audience to presenters will keep the audience concentrating } \\
\text { on the presentation. }\end{array}$ & 4.15 & \\
\hline 7 & $\begin{array}{l}\text { The use of English as a medium of instruction (EMI) is beneficial for the } \\
\text { students. }\end{array}$ & 4.07 & \\
\hline 1 & $\begin{array}{l}\text { The examination for this lecture will use of authentic evaluation, which is } \\
\text { among other things characterised by interview. }\end{array}$ & 3.24 & \\
\hline 1 & $\begin{array}{l}\text { In general the teaching method used in this class drives students to master the } \\
\text { material. }\end{array}$ & 4.17 & \\
\hline 1 & $\begin{array}{l}\text { In general the teaching method used in this class pushes students to master } \\
\text { English. }\end{array}$ & 4.20 & \\
\hline 1 & $\begin{array}{l}\text { In general the teaching method implemented in this class forces students to } \\
\text { prepare for the examination better. }\end{array}$ & 4.20 & 4.02 \\
\hline TOTAL AVERAGE SCORES & \\
\hline
\end{tabular}

Secondary Problem 1

Students' Perceptions of Reqap as a

Presentation Technique

As a presentation technique Reqap does not include the use of EMI and authentic evaluation. The term covers only the reciprocal question and answer presentation with its accompanying rules. This technique which evidently requires participants to actively take part in the class activities demands them to comprehend the material as well. The positive attitude of the students to this technique as signalled by the score it gained (4.06) might be caused by their awareness that this teaching strategy benefited them in some ways. Firstly, it could push them to prepare themselves harder for the class. Secondly, this technique gave them opportunities to get immediate corrections from the lecturer once they occurred. Corrections were primarily on grammar and pronunciation mistakes and were mostly given in the form of echo, which made corrections accepted unhurting. Corrective feedback like this according to Mahdi and Saadany (2013: 26) was indeed beneficial in that it made students empowered and proud of their production when the teacher provided appropriate feedback for their work.

Sheen (2011) assumed that corrective feedback which occured during interaction between a teacher and learners played a role of helping learners to repair impasses in their conversational discourse. The other role corrective feedback plays is to enhance both oral and linguistic accuracy (Ellis, 2009:16). Most importantly, as Hyland and Hyland (2006:83) added feedback was a key element of the scaffolding provided by the teacher to build learner confidence. And the immediate feedback practiced in Reqap was supported by Chan and Cole (1994), who claimed that it was 
usually advisable because it showed students the mistakes in their work and prevented them from practicing errors.

Thirdly, the class was well managed, meaning that from the view of the presenters the class gave them full attention from the audience and from the view of the audience the class provided assurance of clear material presentation as stated in statement 3. Fourthly, Reqap perfectly represents the concept of student-centered learning, whose rationale could be found among other things in the question who was speaking the most in the class, particularly by examining the difference in the teacher talk (indicating teacher-centered teaching) and student talk (indicating a student-centered approach). Unlike other conventional language classrooms which showed that teacher talk time could reach up to $70 \%$ of the total talk (Xiao-yan, 2006: 6), teacher talk time in Reqap was less than $30 \%$.

Student-centered learning as the basis of Reqap was also reflected in the nature of cooperative learning, which as Kagan (1994) asserted could encourage learners to have higher achievement and consequently higher self-esteem and intrinsically motivated. This concept, according to Long and Porter (1985) are beneficial in EFL learning because they provide a low-anxiety environment for learners to increase their language production and heighten their self-confidence. This aspect seemed to compensate the diverse effect of authentic evaluation.

Table 2

Means and Standard Deviations of Students' Perceptions of Reqap as a Presentation Technique

\begin{tabular}{|l|l|l|l|}
\hline \multicolumn{2}{|l|}{ Statements } & $\begin{array}{l}\text { Mean } \\
\text { s }\end{array}$ & SD \\
\hline 1 & $\begin{array}{l}\text { Lecturer's role to determine who will speak first in the presentation makes } \\
\text { students prepare themselves better. }\end{array}$ & 4.32 & \\
\hline 2 & $\begin{array}{l}\text { Lecturer's role as an observer who can interrupt and correct grammatical, } \\
\text { vocabulary, and pronunciation mistakes during presentation is beneficial. }\end{array}$ & 3.98 & 3.66 \\
\hline 3 & $\begin{array}{l}\text { It is logical for the lecturer to stop a student's presentation if the student } \\
\text { cannot speak English satisfactorily because this will affect the whole } \\
\text { presentation. }\end{array}$ & $\begin{array}{l}\text { Presentation as a teching technique boosts students to master the teaching } \\
\text { material. }\end{array}$ & 4.10 \\
\hline 5 & $\begin{array}{l}\text { Questions from presenters to audience can draw better attention from the } \\
\text { audience to what is being delivered by the presenters. }\end{array}$ & 4.17 & \\
\hline 6 & $\begin{array}{l}\text { Questions from audience to presenters will keep the audience concentrating on } \\
\text { the presentation. }\end{array}$ & 4.15 & \\
\hline TOTAL AVERAGE SCORES & 4.06 & \\
\hline
\end{tabular}

Secondary Problem 2

Students' Perception of the Use of EMI

As seen in Table 3, in general students had good attitude towards the use of English as a medium of instruction. As a matter of fact, this finding was in contrast with the writer's conjecture because as far as English is concerned many students still showed apparent weaknesses in the mastery of grammar, vocabulary, and pronunciation. This could logically bring about reluctance to use English before a public for psychological reasons. However, they showed positive stance on EMI as signalled by the score for item 7 (4.07). This finding might also be explained with students' comments on Reqap that Reqap provided them with good opportunities to use English. This was especially true when we know that teacher talk-time in this presentation technique typically took not more than thirty percent of the total talk. This also meant that Reqap was in accordance with the advocacy of class activities which create a favorable language environment so that learners would be immersed in an English-speaking context.

The use of EMI in Reqap was primarily based on several assumptions. First of all, on the ground of the teaching of English across curriculum, Language Testing 1 class was given an extraload of English content. Secondly, as far as the teaching of English as a foreign language is concerned, teaching English monolingually will increase the 
learning of the language, regardless of whatever other languages the learner may know (Phillipson, 1992; Harbord, 1992; Weschler, 1997 and Cook, 2001). On the other hand, teaching English bilingually or using the mother tongue in EFL classroom will prevent the students from acquiring the valuable input in the L2 (Krashen, 1985). Cook (2001) also strongly supports the monolingual approach.
She asserts that using the target language will create successful learning, especially if the learners realize that their maximum exposure to English will develop their capabilities in the target language. Similar view was expressed by Deller and Rinvolucri (2002) who did not support the random use of the mother tongue and warn the language teachers of the negative effects of its over-use in the EFL classrooms.

Table 3

Means and Standard Deviations of Students' Perception of the Use of EMI

\begin{tabular}{|l|l|l|l|}
\hline \multicolumn{2}{|l|}{ Statements } & Means & SD \\
\hline 7 & $\begin{array}{l}\text { The use of English as a medium of instruction (EMI) is beneficial for the } \\
\text { students. }\end{array}$ & 4.07 & \\
\hline
\end{tabular}

Secondary Problem 3

Students' Perception of the Use of Authentic Evaluation

The data analysis which showed the use of authentic evaluation got the second least agreement from the students was not surprising. As Table 4 shows the mean score for this statement is 3.24, which indicated that only a few students agreed with the use of authentic evaluation. The reason for this could be traced from the features of authentic evaluation. As we know, one crucial feature of authentic evaluation in language context is the involvement of language performance for real needs. In other words, as Wiggins (1990) asserts authentic evaluation requires students to be effective performers with acquired knowledge. Students need to directly show what they are capable of and in the case of knowledge they need to tell what they know.
That means they could not rely on others. For those who are not fully ready they would be apprehensive of the test. And, according to Liu (2006) the students might even be more anxious when they knew they had to respond to the teacher and singled out to speak English. In addition, Reqap evaluation applied evaluation system used in collaborative teching method in which students' achievement was based on individual not group performance. This was in contrast with cooperative method, where each member's answer represents a collective idea of the group, no matter how good or poor the answer is (Flowerdew, 1998). Besides, if we have a look at Horwitz, Horwitz and Cope's FLCAS (1986) two of the three aspects of anxiety measured deal with evaluation: fear of negative evaluation and test anxiety.

Table 4

Means and Standard Deviations of Students' Perception of the Use of Authentic Evaluation

\begin{tabular}{|l|l|l|l|}
\hline \multicolumn{2}{|l|}{ Statements } & Means & SD \\
\hline 11 & $\begin{array}{l}\text { The examination for this lecture will use of authentic evaluation, which is } \\
\text { among other things characterised by interview. }\end{array}$ & 3.24 & \\
\hline
\end{tabular}

Secondary Problem 3

Students' Perceptions of the Most Blocking Language Elements

Valid knowledge of what language elements which most seriously block communication flow is definitely important for the EMI implementation policy. The knowledge would be very useful in the decision of which part(s) of the language would receive more emphasis in the development of language curriculum. With the right emphasis in the curriculum we could hope that the products of the process would show better quality in what was being emphasized. As seen in Table 5 , students felt that grammar had been the most blocking element when it came to speaking in English (4.07) compared to pronunciation (3.94), and vocabulary (3.93). This finding implied that the teaching of grammar had to receive more attention from 
usually advisable because it showed students the mistakes in their work and prevented them from practicing errors.

Thirdly, the class was well managed, meaning that from the view of the presenters the class gave them full attention from the audience and from the view of the audience the class provided assurance of clear material presentation as stated in statement 3. Fourthly, Reqap perfectly represents the concept of student-centered learning, whose rationale could be found among other things in the question who was speaking the most in the class, particularly by examining the difference in the teacher talk (indicating teacher-centered teaching) and student talk (indicating a student-centered approach). Unlike other conventional language classrooms which showed that teacher talk time could reach up to $70 \%$ of the total talk (Xiao-yan, 2006: 6), teacher talk time in Reqap was less than $30 \%$.

Student-centered learning as the basis of Reqap was also reflected in the nature of cooperative learning, which as Kagan (1994) asserted could encourage learners to have higher achievement and consequently higher self-esteem and intrinsically motivated. This concept, according to Long and Porter (1985) are beneficial in EFL learning because they provide a low-anxiety environment for learners to increase their language production and heighten their self-confidence. This aspect seemed to compensate the diverse effect of authentic evaluation.

Table 2

Means and Standard Deviations of Students' Perceptions of Reqap as a Presentation Technique

\begin{tabular}{|l|l|l|l|}
\hline \multicolumn{2}{|l|}{ Statements } & $\begin{array}{l}\text { Mean } \\
\text { s }\end{array}$ & SD \\
\hline 1 & $\begin{array}{l}\text { Lecturer's role to determine who will speak first in the presentation makes } \\
\text { students prepare themselves better. }\end{array}$ & 4.32 & \\
\hline 2 & $\begin{array}{l}\text { Lecturer's role as an observer who can interrupt and correct grammatical, } \\
\text { vocabulary, and pronunciation mistakes during presentation is beneficial. }\end{array}$ & 3.98 & 3.66 \\
\hline 3 & $\begin{array}{l}\text { It is logical for the lecturer to stop a student's presentation if the student } \\
\text { cannot speak English satisfactorily because this will affect the whole } \\
\text { presentation. }\end{array}$ & $\begin{array}{l}\text { Presentation as a teching technique boosts students to master the teaching } \\
\text { material. }\end{array}$ & 4.10 \\
\hline 5 & $\begin{array}{l}\text { Questions from presenters to audience can draw better attention from the } \\
\text { audience to what is being delivered by the presenters. }\end{array}$ & 4.17 & \\
\hline 6 & $\begin{array}{l}\text { Questions from audience to presenters will keep the audience concentrating on } \\
\text { the presentation. }\end{array}$ & 4.15 & \\
\hline TOTAL AVERAGE SCORES & 4.06 & \\
\hline
\end{tabular}

Secondary Problem 2

Students' Perception of the Use of EMI

As seen in Table 3, in general students had good attitude towards the use of English as a medium of instruction. As a matter of fact, this finding was in contrast with the writer's conjecture because as far as English is concerned many students still showed apparent weaknesses in the mastery of grammar, vocabulary, and pronunciation. This could logically bring about reluctance to use English before a public for psychological reasons. However, they showed positive stance on EMI as signalled by the score for item 7 (4.07). This finding might also be explained with students' comments on Reqap that Reqap provided them with good opportunities to use English. This was especially true when we know that teacher talk-time in this presentation technique typically took not more than thirty percent of the total talk. This also meant that Reqap was in accordance with the advocacy of class activities which create a favorable language environment so that learners would be immersed in an English-speaking context.

The use of EMI in Reqap was primarily based on several assumptions. First of all, on the ground of the teaching of English across curriculum, Language Testing 1 class was given an extraload of English content. Secondly, as far as the teaching of English as a foreign language is concerned, teaching English monolingually will increase the 
those concerned, both in terms of method and content of instruction.
With this, we could hope that Reqap would be able to perform best.

Table 5

Students' Perceptions of the Most Blocking Language Elements

\begin{tabular}{|l|l|l|}
\hline \multicolumn{2}{|l|}{ Statements } & Means \\
\hline 8 & Grammar is the most blocking element of English when I speak in the language. & 4.07 \\
\hline 9 & Vocabulary is the most blocking element of English when I speak in the language. & 3.93 \\
\hline 10 & $\begin{array}{l}\text { Pronunciation is the most blocking element of English when I speak in the } \\
\text { language. }\end{array}$ & 3.94 \\
\hline
\end{tabular}

Secondary Problem 3

Students' Perceptions of Reqap as an

Alternative Method for Other Classes

Very positive perceptions of Reqap as a method (4.06) and doubtful attitude toward the use of the method in other relevant classes (3.17) might first draw confusion. However, if we take some assumptions into consideration the problem might not look as complicated as we thought. First, student-centered learning requires lots of work to do and this means demanding time and energy.
There will be subsequent problems if the classes are plotted at the beginning semesters, since students have to take ten to twelve classes in one semester. Second, some relevant classes can be too hard if EMI is to be put into practice, especially the ones which involve cultural discussion. Third, authentic evaluation entails lots of work to do. With these in mind, it could easily be understood if students feel that more than one class implementing Reqap would be too hard for them.

Table 6

Means and Standard Deviations of Students' Perception of Reqap as an Alternative Method for Other

\begin{tabular}{|l|l|l|l|}
\hline \multicolumn{2}{|l|}{ Statements } & Means & SD \\
\hline 1 & $\begin{array}{l}\text { I hope this method (Reqap) can be an alternative method for other relevant } \\
\text { classes. }\end{array}$ & 3.17 & \\
\hline
\end{tabular}

Main Problem 2

\section{Students' Anxiety Level}

If we look at Horwitz, Horwitz, and Cope's (1986) definition of anxiety in relation to language classroom, this concept actually refers to a distinct complex of self-perceptions, beliefs, feelings and behaviors related to classroom learning arising from the uniqueness of the language learning (p. 128). For the reason, occurrances of this state of behavior will eventually affect performance. As Qian and Seepho (2012) believe learning will hardly be productive if learners are exposed to a high-anxiety learning environment. Many studies also demonstrated a negative relationship between anxiety and academic performance (MacIntyre \& Gardner, 1991; Horwitz, 2001).
Following Horwitz's (1986) theory anxiety in this study is classified into Mild (3-6), Moderate (7-9), Severe (10-12), and Panic (1315). As the number of statements in Horwitz's FLCAS is 33 and the number of statements in this study was limited to only 3 , the analysis result was different. However, the scoring system followed that of Horwitz.The question which arose regarding Reqap was of course whether the students felt anxious when the activities were in progress and at what level. Data analysis showed that students anxiety reached Severe level (10.93), the second highest before Panic level. This might be caused by the main parts of the method, ranging from random pointing to authentic evaluation. 
Table 7

Students' Anxiety Level

\begin{tabular}{|l|l|l|}
\hline \multicolumn{2}{|l|}{ Statements } & $\begin{array}{l}\text { Score } \\
\text { s }\end{array}$ \\
\hline 1 & I feel very nervous knowing that I have to master the whole material for the & 164 \\
\hline 1 & presentation. & I feel very nervous bacause I have to speak entirely in English during the class. \\
7 & & 134 \\
\hline 1 & I feel very nervous when I remember that the final examination will be given in & 150 \\
8 & authentic evaluation (interview). & 10.93 \\
\hline AVERAGE SCORE (the sum divided by 41) & \\
\hline
\end{tabular}

\section{Secondary Problem 1}

\section{Most Influential Factors of Anxiety}

The next question after finding the level of anxiety was logically, what Reqap elements caused the students to feel anxious most. Of the many factors, the writer was particularly interested in three main elements of Reqap: having to master the whole material for the presentation, having to speak entirely in English during Reqap, and the use of authentic evaluation for the class.

As explained in the Data Analysis above, the students were asked to rank three elements of Reqap in an order of their influence over anxiety.
The results showed that the use of authentic evaluation scored most (102), meaning that it was ranked one by largest part of the respondents. This element was followed by having to master the whole material for the presentation (82), and the last was having to speak entirely in English during the class. It demonstrated the consistency of authentic evaluation as the most worrying aspect of the class. A rather bright picture was presented by the use of English as a medium of instruction, in which it confirmed students' light feeling for its implementation.

Table 8

Most Influential Factors of Anxiety

\begin{tabular}{|l|l|l|}
\hline \multicolumn{2}{|l|}{ Statements } & Scores \\
\hline A & Having to master the whole material for the presentation. & 82 \\
\hline B & Having to speak entirely in English during the class. & 63 \\
\hline C & The use of authentic evaluation (interview) for the exam. & 102 \\
\hline
\end{tabular}

Main Problem 3

Students' Comments and Expectations of Reqap

Following are comments and expectations on Reqap given by the students through the open questionnaire. The comments and expectations are organized in two parts (comments and expectations) and each part is divided into three (Reqap, EMI, and authentic evaluation). The respondents' sentences are substantially in tact. Change was made to the grammar only.

Table 9

\begin{tabular}{|l|l|}
\hline \multicolumn{2}{|c|}{ COMMENTS } \\
\hline $\begin{array}{l}\text { N } \\
\mathbf{0}\end{array}$ & REQAP \\
\hline 1 & It is interesting. \\
\hline 2 & It is a kind of challenge. \\
\hline 3 & Students will try their best to show what they have. \\
\hline 4 & It gives students motivation to study. \\
\hline 5 & This enables lecturer to give individual evaluation, not group \\
\hline
\end{tabular}




\begin{tabular}{|c|c|}
\hline 6 & This will help students increase their speaking skill. \\
\hline 7 & Students will be forced to focus on the presentation. \\
\hline 8 & This requires that students are at least at pre-advanced level of English. \\
\hline 9 & $\begin{array}{l}\text { Reciprocal Q/A is fair, meaning that not only audience is given chance to pose questions but } \\
\text { also the presenters. }\end{array}$ \\
\hline 10 & Having to ask after the presentation can develop critical thinking among students. \\
\hline 11 & It is good though some will feel nervous or even depressed. \\
\hline 12 & $\begin{array}{l}\text { The reciprocal Q/A presentation technique forces the presenters to master not only parts but } \\
\text { all of the material being discussed. This is very demanding. }\end{array}$ \\
\hline 13 & $\begin{array}{l}\text { Though it looks demanding and burdensome this technique is effective in making students } \\
\text { active. }\end{array}$ \\
\hline 14 & This technique gives students more responsibility to master the material \\
\hline No & EMI \\
\hline 1 & It is difficult to apply, students still use codeswitching even in Speaking classes. \\
\hline 2 & It forces the students to speak English. \\
\hline 3 & It makes sense because English students must speak English. \\
\hline 4 & It will bring about awareness of the importance of grammar. \\
\hline 5 & EMI makes students aware of the importance of having sufficient vocabulary. \\
\hline 6 & $\begin{array}{l}\text { This is good, as this enables lecturer to monitor the extent to which the students have } \\
\text { mastered the language, especially the grammar. }\end{array}$ \\
\hline 7 & $\begin{array}{l}\text { EMI in LT class is good because for Indonesian students it is difficult to find opportunities to } \\
\text { practice English. }\end{array}$ \\
\hline 8 & $\begin{array}{l}\text { The problem with EMI is that the mind and the words do not get along well. This is because } \\
\text { we feel nervous. }\end{array}$ \\
\hline No & AUTHENTIC EVALUATION \\
\hline 1 & It will enable lecturers to identify students learning difficulties. \\
\hline 2 & Good because, it gives the actual portrtait of each student. \\
\hline 3 & Some students have psychological problem (nervous) and this may lead to wrong picture. \\
\hline 4 & It has positive backwash to students, they will study harder. \\
\hline 5 & This has positive backwash on presentation. \\
\hline
\end{tabular}

\begin{tabular}{|l|l|}
\hline \multicolumn{2}{|c|}{ RECOMMENDATIONS } \\
\hline No & REQAP \\
\hline 1 & Limit the questions from the presenters to only 2 or 3. \\
\hline 2 & $\begin{array}{l}\text { Stopping students students when presentation is in progress is not suggested, as this will } \\
\text { disrupt concentration. }\end{array}$ \\
\hline 3 & $\begin{array}{l}\text { Reminding students to speak clearly will definitely disturb focus, but this will boost students } \\
\text { motivation to prepare better. }\end{array}$ \\
\hline 4 & Lecturers must give a review at the end of the class. \\
\hline 5 & Please, try to make some kind of intermezo to make the class more relaxed. \\
\hline 6 & Please give time for motivation either at the beginning ar at the end of the class. \\
\hline No & EMI \\
\hline 1 & Please give motivation so that students will not feel nervous when speaking. \\
\hline
\end{tabular}




\begin{tabular}{|l|l|}
\hline No & AUTHENTIC EVALUATION \\
\hline 1 & Do not assess only at the end but also during the process. \\
\hline
\end{tabular}

Since the above comments and recommendations were made by individual students, they did not represent each other's ideas. Besides, some students missed the first meeting that he might have given comments or recommendations that reflected lack of important information regarding the rules of the class.

\section{References}

AL-Harbi, A. (2010). Mother Tongue Maintenance and Second Language Sustenance. A Two Way Language Teaching Method., TESOL Journal. 2 (1), pp.144-158.

Alqahtani, Abdulmuhsen Ayedh and Eihab Khaled Al-enzi . 2011. EFL Teachers' Feedback to Oral Errors in EFL Classroom: Teachers' Perspectives. TESOL Journal. 2 (1) pp.214-232

Astin, A., (1993). What matters in college. San Francisco, CA: Jossey-Bass.

Azmi (2015). Teachers' Perception of the Ratio of Teacher Talk Time (TTT) and Student Talk Time (STT) in English Classrooms at Three Junior High Schools in Purwokerto. Thesis. Purwokerto: Universitas Muhammadiyah Purwokerto

Bruner, J. (1985). Vygotsky: An historical and conceptual perspective. Culture, communication, and cognition: Vygotskian perspectives. London: Cambridge University Press.

Chan, L., \& Cole, Peter G. (1994). Teaching principles and practice second edition. Australia: Prentice Hall of Australia PTY Ltd.

Choudary, Javid Z. (2011). Saudi Medical Undergraduates' Perceptions of Their Preferred Learning Styles and Assessment Techniques. Arab World English Journal. 2 (2), 40-70

Cook, V. (2001). Using the First Language in the Classroom. The Canadian Modern Language Review, 57(3), 402-423. Retrieved July 15，2010 from http:// www.homepage.ntlworld.com/ vivian.c/.../L1inClass.h

Deller, S. \& Rinvolucri, M. (2002). Using the Mother Tongue. Making the Most of the Learner's Language. London: Baskerville Press Ltd.
Dulay, H.C., Burt, M.K., \& Krashen, S. (1982). Language Two. NewYork, NY: Oxford University Press.

Ellis, R. (2009). Corrective feedback and teacher development. L2 Journal. 1, 3-18. University of California.

Ellis, R., Loewen, S., \& Erlam, R. (2006). Implicit and explicit corrective feedback and the acquisition of L2 grammar. Studies of Second Language Acquisition, 28, 339368.

Farrah, Mohammed Abdul Hakim. (2011). Attitudes Towards Collaborative Writing Among English Majors in Hebron University. Arab World English Journal. 2 (4) pp. 136-170.

Harbord, J. (1992). The Use of the Mother Tongue in the Classroom. ELT Journal, 46, 350-355.

Horwitz, E. K.(2001). Language anxiety and achievement. Annual Review of Applied Linguistics, 21(1), 112-126.

Horwitz, E. K., Horwitz, M. B., \& Cope, J. (1986). Foreign language classroom anxiety. The Modern Language Journal, 70 (2), 125-132.

Hyland, K., \& Hyland, F. (2006). Feedback on second language students' writing. London: Cambridge University Press.

Johnson, D. W., \& Johnson, R. T. (1999). Learning together and alone: Cooperative, competitive, and individualistic learning. Boston: Allyn \& Bacon.

Kagan, S. (1994). Cooperative learning. (San Clemente, Kagan Cooperative Publishing).

Kolb, D. A. (1984). Experiential learning: Experience as the source of learning and development. Englewood Cliffs, NJ: Prentice-Hall.

Krashen, S. \& Terrell, T. (1983). The Natural Approach: Language Acquisition in the Classroom. Oxford: Pergamon.

Long, M. H., \& Porter, P. A. (1985). Group work, interlanguage and second language acquisition. TESOL Quarterly, 19/2: 207-228.

MacIntyre, P. D., \& \& Gardner, R. C. (1991). Methods and results in the study of anxiety and language learning: A review of the literature. Language Learning, 41, 85 $-117$. 
Mahdi, D., \& Saadany, Noha E. (2013). Oral feedback in EFL classroom. Sweden: Malmo University.

McKeown, John. (2012). Promoting Cooperative Learning in ELT Classes through the Use of CoRT Thinking Tools. Arab World English Journal. 3(3). pp. 154167

Phillipson, R. (1992). Linguistic Imperialism. Oxford: Oxford University Press.

Qian, Li and Sirinthorn Seepho. (2012). Foreign Language Speaking Anxiety Reduction through a Jigsaw Activity. Arab World English Journal. 4(2). P297 305.

Richards, J. (1971). A Non-Contrastive Approach to Error Analysis. English Language Teaching Journal. 25(3).204-219. (intereference of L1 to L2)

Sheen, Y. (2011). Corrective feedback, differences and second language learning. Dordrecht: Springer.

Spada, N. \& M. Fröhlich. 1995. Communicative orientation of language teaching observation scheme. Coding conventions and applications. Sydney: NCELTR, Macquarie University

Vygotsky, L.S. (1978). Mind in society: the development of higher psychological processes. (M. Cole, V. John-Steiner, S. Scriber, \& E. Souberman, Eds. And Trans.) Cambridge, MA: Harvard University Press.

Weschler, R. (1997). Uses of Japanese (L1) in the English Classroom: Introducing the Functional Translation Method. The Internet TESL Journal, 3(1), 1-12. Retrieved August 25, 2010 from http://iteslj.org/ Articles/Weschler-UsingL1.html.

Wiggins, Grant (1990). The case for authentic assessment. Practical Assessment, Research $\mathcal{E}$ Evaluation, 2(2). Retrieved August 20, 2015 from http://PAREonline.net/ getvn.asp? $v=2 \& n=2$. This paper has been viewed 239,333 times since 11/13/1999.

Xiao-yan. MA. (2006) Teacher Talk and EFL in University Classrooms. China: Congqing Normal University and Yangtze Normal University 